\title{
Yoğuşmalı Kombilerin Isı Değiştiricisinde Meydana Gelen Korozyon Hasarının İncelemesi
}

\author{
Harun MINDIVAN ${ }^{1 *}$
}

Geliş / Received: 23/05//2019

Revize / Revised: 15/07/2019

Kabul / Accepted: 02/09/2019

ÖZ

$\mathrm{Bu}$ çalışmada, kombilerde yoğuşma 1sı değiştiricisi imalatında yaygın bir kullanım alanına sahip olan Alüminyum - Silisyum alaşım sistemine ait Etial-141 alaşımının korozyon hasarı incelenmiştir. Korozyona uğrayan ve uğramayan kanatlı borulu 1sı değiştirici numunelerin iç, yan yüzeyleri ve kesitleri optik mikroskopta incelenmiştir. Bu numuneler potansiyodinamik polarizasyon yöntemi kullanılarak \% 3,5 NaCl çözelti içerisinde korozyon işlemine tabi tutulmuşlardır. Yapılan bu deneysel çalışmalardan elde edilen sonuçlarda, korozyona uğrayan 1sı değiştiricilerde korozyonun nedeni alüminyum 1sı değiştirici ile bakır borunun birbirleri ile temas halinde bulunmasından ve aralarından akım geçişine müsait bir ortamda bulunmalarından dolayı oluşan galvanik korozyondur. Korozyona maruz kalmayan 1sı değiştiricisinin yüzey ve kesitinden alınan alüminyum alaşımının $\% 3,5 \mathrm{NaCl}$ çözeltisi içerisindeki potansiyodinamik polarizasyon eğrileri ve korozyon yüzeyleri incelendiğinde korozyonun oyuklanma şeklinde geliştiği ve benzer korozyon davranışı sergilediği tespit edilmiştir.

Anahtar Kelimeler-Alüminyum Alaşımı, Korozyon, Isı Değiștirici.

1*Sorumlu yazar iletişim: harun.mindivan@bilecik.edu.tr (https://orcid.org/0000-0003-3948-253X)

Department of Mechanical Engineering, Bilecik Şeyh Edebali University, Bilecik 


\title{
Corrosion Damage Analysis in Heat Exchangers of Condensing Boilers
}

\begin{abstract}
Corrosion damage of Etial-141 alloy belonging to the Aluminum - Silicon alloy system, which is widely used in condensing heat exchanger production in combi boilers has been investigated in this study. Internal, side surfaces and cross-sections of samples obtained with heat exchanger subjected to corrosion process were compared to non-corroding samples by an optical microscope. These samples were subjected to potentiodynamic polarization in a $3.5 \% \mathrm{NaCl}$ solution. In the results obtained from these experimental studies, corrosion in heat exchangers is due to the fact that the aluminum heat exchanger and the copper pipe are in contact with each other and galvanic corrosion due to their presence in an environment suitable for flow passage. The corrosion behaviour of the aluminum alloy taken from the surface and cross-section of the heat exchanger which is not exposed to the corrosion was evaluated by potentiodynamic polarisation measurements in $3.5 \% \mathrm{NaCl}$ solution. The results obtained from these experimental studies, corrosion developed in the form of pitting and exhibited similar corrosion behavior.
\end{abstract}




\section{GİRIŞ}

Isı değiştiricileri, 1sıl temas halinde bulunan farklı sıcaklıktaki iki veya daha fazla akışkan arasında 1sı geçişinin sağlandığı cihazlardır. Değiştiricinin görevi bir akışkanı soğutmak ya da diğer akışkanı 1sıtmaktır. Ya da aynı anda her ikisini birden gerçekleştirmektir. Isı değiştiriciler, iklimlendirme sistemlerinde, atık su tesislerinde, kâğıt üretiminde, termik santrallerde, kimyasal işlemlerde, atık ısının geri kazanılmasında ve diğer pek çok endüstride yaygın kullanım alanına sahiptir [1]. Isı değiştiricileri endüstrinin en önemli 1Sı tekniği cihazları olup, bunlar buharlaştırıeı, yoğuşturucu, 1sıtıcı, soğutucu gibi değişik isimler altında kimya, petrokimya endüstrilerinin, soğutma, ısıtma ve iklimlendirme tesislerinin hemen her kademesinde değişik tip ve kapasitelerde görülebilir. Makine ve kimya mühendisliği eğitimi açısından bakıldığında ısı değiştiricileri bu mühendislik kollarının temel konuları olan, malzeme, mukavemet, termodinamik ve 1sı geçişi bilim dallarının hepsini birden aynı anda içeren bu bilim dallarına ait çok iyi bir uygulamadır. Anlaşılabileceği gibi 1S1 değiştiriciler günlük hayatımızda her zaman kullanılan bir yapıdır. Buhar kazanı, mekanik soğutma devresi, bir iklimlendirme tesisatının çeşitli kademeleri, bilgisayar işlemcisinin soğutulması uygulama alanlarına örnek olarak verilebilir [2].

Şekil 1' de gösterildiği gibi, sistemdeki kanatlı borulu 1sı değiştiricisi, atık ısı geri kazanım amacıyla yoğuşmalı kombilerde atık ısıdan faydalanmak için kullanılırlar. Gaz ilk ateşleme ile yanarak sıcaklığı yaklaşık $1000{ }^{\circ} \mathrm{C}$ ' ye kadar çıkmaktadır. Ana 1sı değiştiricinin borusundan geçen su ile yanan gaz arasında 1sı transferi gerçekleşerek, su 1sısı artar, gaz ise kanatçıklardan geçtikten sonra doğal olarak 1sısı azalır. Bu gaza atık gaz 1Sısı denilmektedir. Sıcaklığ 1 yaklaşık 150 C' ye düşen atık gaz, yoğuşma 1sı değiştiricisine gönderilerek daha küçük bir 1sı transferi gerçekleşmektedir. Bu olaydan sonra ikinci kez 1sı değiştiricisinden çıkan gaz, bazı emisyonlarla bacadan dışarıya salınır. Yoğuşmalı kombilerin yoğuşma 1sı değiştiricisinde sürekli olan bu işlem bir zaman sonra, 1Sı değiştiricisinde, montajlı olan parçalarda uyuşmayan malzeme ortamı olduğundan ve bu ortam sulu yani elektrolitli bir ortam olduğu için, boruların içinde korozyon meydana gelmektedir.

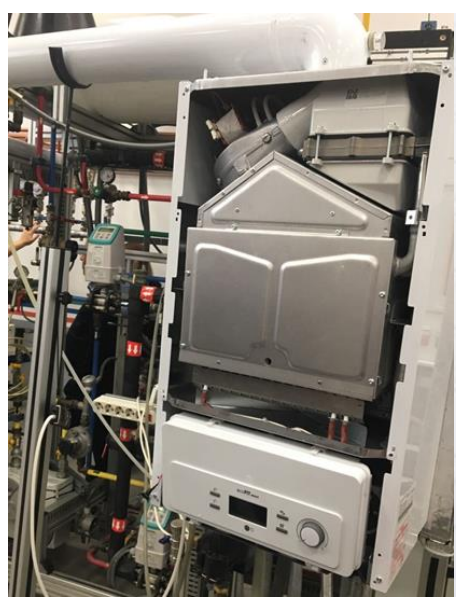

(a)

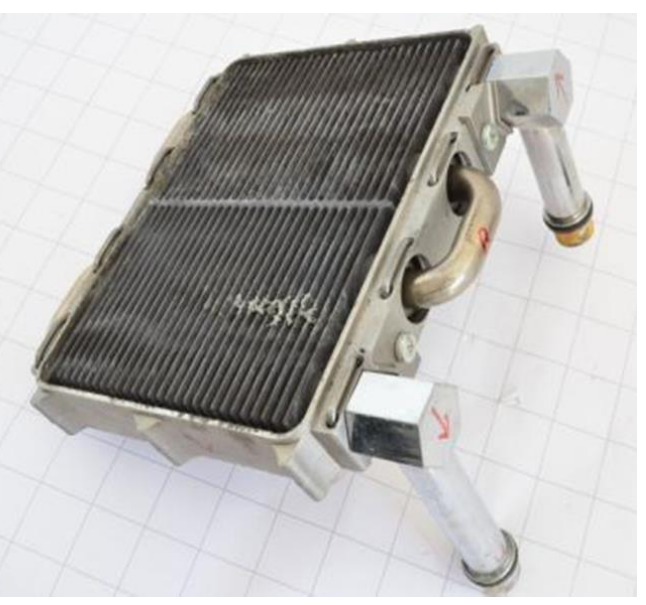

(b)

Şekil 1. (a) Isı değiştiricinin kullanıldığı (b) yoğuşmalı kombi görüntüsü.

Is1 değiștirici imalatında Etial-140, Etial-141, Etial-171 ve Etial-180 gibi Alüminyum - Silisyum alaşımları kullanılmaktadır. Alüminyum, yüksek elektronegatif potansiyelli bir metaldir. Normal denge gerilimi 1,67 V’tur. Buna rağmen, alüminyumun dış hava şartlarına, bir çok zayıf asit çözeltilerine, çoğu nötr çözeltilere ve suya karşı oldukça yüksek bir dayanımı vardır. Havalandırılmış çözeltilerde pasif durum kararlılığına göre alüminyum, kromla birlikte titanyumdan sonra ikinci sıradadır. Örneğin bakır gibi yarı soy bir metalin bile klorürlü çözeltilerdeki korozyon hızı alüminyumdan daha yüksektir. Alüminyumun korozyon direncini yüzeye sıkı bağlanmış olan alüminyum oksit tabakası sağlar. Bu tabaka hasar gördüğünde, birçok ortamda yeniden oluşur. Bu özelliği ile alüminyum çok kullanılan yapısal metallerden biri olmuştur. Korozyona uğrayan yüzey tekrar atmosferik ortamda bırakıldığında $10 \AA$ kalınlığında oksit tabakası oluşur ve bu tabaka alüminyumu 
korozyondan korumada oldukça etkilidir. Alüminyum alaşımlarında görülen korozyon tipleri tanelerarası korozyon, tabaka korozyonu, gerilmeli korozyon çatlaması ve oyuklanma korozyonudur [3, 4].

Bu çalışmada Etial-141 alaşımından imal edilen korozyona uğrayan ve uğramayan kanat yüzeyli borulu 1S1 değiştiricide korozyonun nasıl geliştiğini görmek için kanat yüzeyli borulu 1sı değiştirici kesitinden numune alınıp hem metalografik çalışma hem de elektrolitik korozyon deneyleri gerçekleştirilmiştir.

\section{DENEYSEL ÇALIŞMA}

$\mathrm{Bu}$ çalışmada, incelenen reküperatöre ait korozyon hasarına maruz kalmayan ve korozyon hasarına maruz kalan kanat yüzeyli borulu 1s1 değiştiricilerin genel ve kesit görüntüleri Şekil 2'de verilmiştir. Isı değiştirici imalatında kimyasal bileşimi ile genel özellikleri Tablo 1 ve 2'de verilmiş olan Etial-141 kalite alüminyum alaşımı kullanılmıştır.

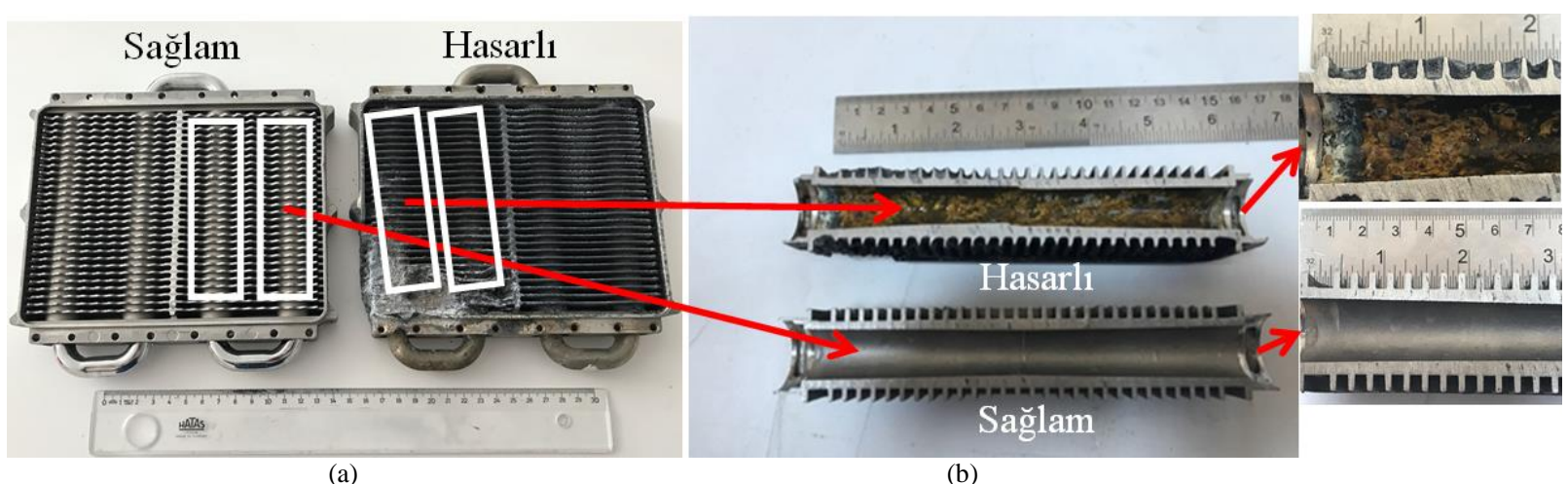

Şekil 2. İncelenen reküperatöre ait korozyon hasarına maruz kalmayan ve korozyon hasarına maruz kalan kanat yüzeyli borulu 1Sı değiştiricilerin (a) genel ve (b) farklı büyütmelerdeki kesit görüntüleri.

Tablo 1. Kullanılan alüminyumun kimyasal bileşimi.

\begin{tabular}{lcccccccccc}
\hline \multirow{2}{*}{ Alaşım } & \multicolumn{10}{c}{ Kimyasal Bileşim, \% Ă̆. } \\
\cline { 2 - 12 } & $\mathrm{Fe}$ & $\mathrm{Si}$ & $\mathrm{Cu}$ & $\mathrm{Mn}$ & $\mathrm{Mg}$ & $\mathrm{Zn}$ & $\mathrm{Ni}$ & $\mathrm{Ti}$ & $\mathrm{Pb}$ & $\mathrm{Sn}$ \\
\hline Etial-141 & 1 & $11.5-13.5$ & 0.2 & 0.3 & 0.2 & 0.1 & 0.1 & 0.15 & 0.1 & 0.05 \\
\hline
\end{tabular}

Tablo 2. Kullanılan Etial-141 alüminyum alaşımının genel özellikleri.

\begin{tabular}{|c|c|c|c|c|c|c|c|c|}
\hline Alaşım & $\begin{array}{c}\text { Özgül } \\
\text { Ǎ̆ırlık } \\
\left(\mathrm{gr}^{\prime} \mathrm{cm}^{3}\right)\end{array}$ & $\begin{array}{c}\text { Ergime } \\
\text { Aralığı } \\
\left({ }^{\circ} \mathrm{C}\right)\end{array}$ & $\begin{array}{l}\text { Isisal İletkenlik } \\
\left(\mathbf{c a l} / \mathrm{cm}^{\circ}{ }^{\circ} \mathrm{C}\right)\end{array}$ & $\begin{array}{c}\text { Korozyon } \\
\text { Dayınımı }\end{array}$ & Dökülebilirlik & İşlenebilme & $\begin{array}{c}\text { Anodik } \\
\text { Oksidasyon }\end{array}$ & $\begin{array}{c}\text { Özellikler ve } \\
\text { Kullanım } \\
\text { Yerleri }\end{array}$ \\
\hline Etial-141 & 2.66 & $575-585$ & 0.29 & Çok İyi & Mükemmel & Orta & $\begin{array}{c}\text { Sadece Yüzey } \\
\text { Korumada }\end{array}$ & $\begin{array}{c}\text { Karışık ince } \\
\text { cidarlı } \\
\text { basınçlı } \\
\text { döküm }\end{array}$ \\
\hline
\end{tabular}

Korozyona maruz kalan ve kalmayan 1sı değiştiricilerinde korozyon etkisinin izlenmesi amacı ile numunelerin yüzeyi, enine kesitleri kesilmiş ve metalografik incelemeler için hazırlanmıştır. Daha sonra metalografik olarak zımparalanan ve parlatılan numuneler Keller dağlayıcısı $\left(\% 2,5 \mathrm{HNO}_{3}, \% 1,5 \mathrm{HCl}, \% 1 \mathrm{HF}\right.$ ve $\% 95$ saf su) ile dağlanarak optik mikroskop incelemelerine hazır hale getirilmiştir. Dağlanmış numunelerin yüzeyi ve enine kesitleri Nikon marka Eclipse LV150 model optik mikroskopta (OM) farklı büyütmelerde incelenerek oluşan korozyonun derecesi belirlenmiştir. Şekil 3'de incelenen 1sı değiştiricinin iç yüzeyi, yan yüzeyi ve kesiti tanımlanmıştır. 


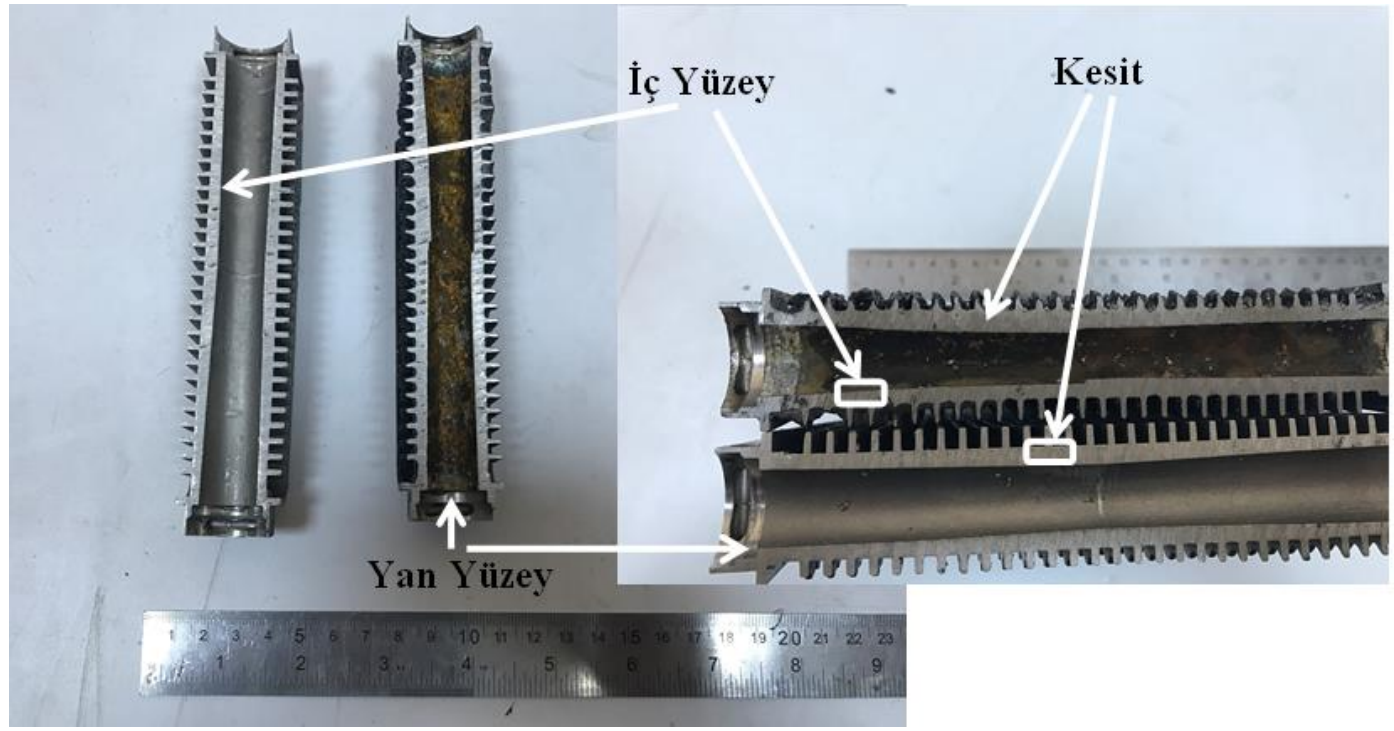

Şekil 3. İncelenen 1sı değiştiricide tanımlanan iç yüzey, yan yüzey ve kesit bölgeleri.

Elektrolitik korozyon deneylerinde, çalışma elektrodu olan kaplanmış numunelerin yaklaşık $0,5 \mathrm{~cm}^{2}$, lik yüzey alanı çözeltiye temas ettirilmiştir. Deney çözeltisi olarak \% 3,5'lik $\mathrm{NaCl}$ çözeltisi kullanılmıştır. Elektrolitik korozyon deneylerinde bilgisayar kontrollü bir potansiyostat/galvonostat cihazı kullanılmıştır. Korozyon deney hücresi içerisine, çalışma elektrotu olarak deney numuneleri, karşıt elektrot olan platin tel (\% 99,99 saflıkta) ve referans elektrot olarak da doygun $\mathrm{Ag} / \mathrm{AgCl}$ elektrodu yerleştirilmiştir. Korozyon hücresinin şematik görünüşü Şekil 4'de verilmiştir. Elektrokimyasal deneylerin tümünde başlangiçta önce denge potansiyeline $\left(\mathrm{E}_{\mathrm{kor}}\right)$ ulaşılması beklenmiş, denge potansiyeline ulaşıldıktan sonra potansiyodinamik polarizasyon eğrileri elde edilmiştir. Bunun için denge potansiyelinin $-1 \mathrm{~V}$ aşağısından $1 \mathrm{~V}$ yukarısına kadar yaklaşık $1 \mathrm{mV} / \mathrm{s}$ tarama hızıyla katodikten anodik yöne doğru polarizasyon yapılmış ve polarizasyon diyagramları oluşturulmuştur.

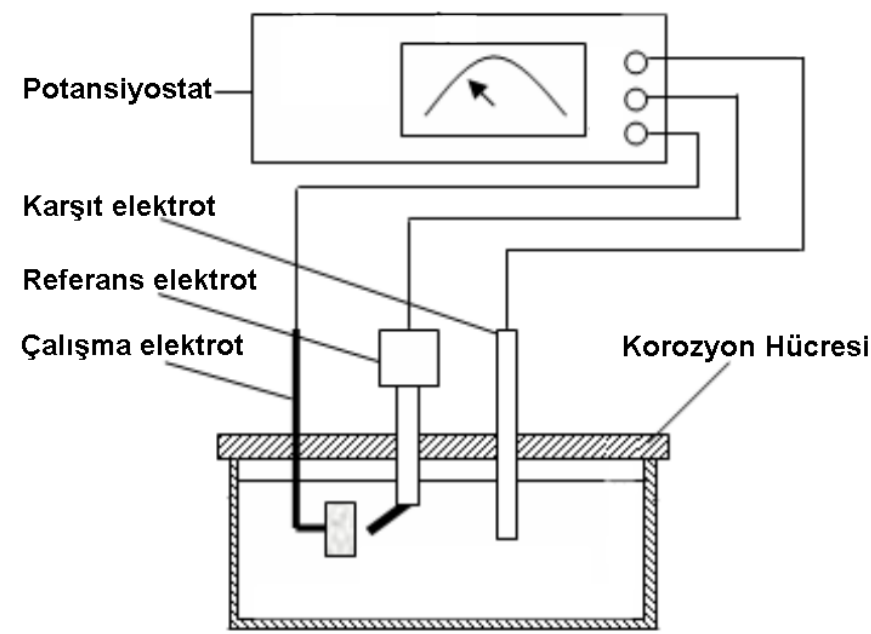

Şekil 4. Elektrolitik korozyon deney düzeneğinin şematik gösterimi. 


\section{SONUÇLAR VE TARTIŞMA}

Aluminyum, yüksek elektronegatif potansiyelli bir metaldir. Normal denge gerilimi -1,67 V`tur. Kuvvetli negatif potansiyelinden dolayı, 1Sı değiştiricilerinde kullanılan bakır gibi elektropozitif metalle temasta olan alüminyum alaşımlarında galvanik korozyon dikkate alınmalıdır [5]. Korozyona maruz kalan reküperatör sistemi incelendiğinde bakır boru ve alüminyum 1sı değiştiricinin temasta olduğu bölgede galvanik korozyondan dolayı korozyon hasarının ciddi olduğu Şekil 5'de görülmektedir. Korozyona maruz kalan 1sı değiştirici ve korozyona maruz kalmayan sağlam 1sı değiştiricisinin iç yüzey, yan yüzey ve kesiti incelenen alüminyum alaşımının OM görüntüleri Şekil 6'da verilmiştir. Korozyona maruz kalan 1sı değiştiriciden alınan numunelerin kesit görüntülerinde $\sim 40 \mu \mathrm{m}$ derinliğinde oyuklar meydana gelmiştir. Ancak korozyona maruz kalan 1s1 değiştiriciden alınan numunelerin iç yüzey ve yan yüzeydeki oyukların derinliği sırasıyla $20 \mu \mathrm{m}$ ve $8 \mu \mathrm{m}$ olup, kesit ile karşılaştırıldığında dip bölgelerdeki oyuklar kadar derin değildir. Korozyona maruz kalmayan sağlam ısı değiştiricisinin elektrolitik korozyon deney sonrası iç yüzey, yan yüzey ve kesitleri ise benzer davranış sergilemiştir.
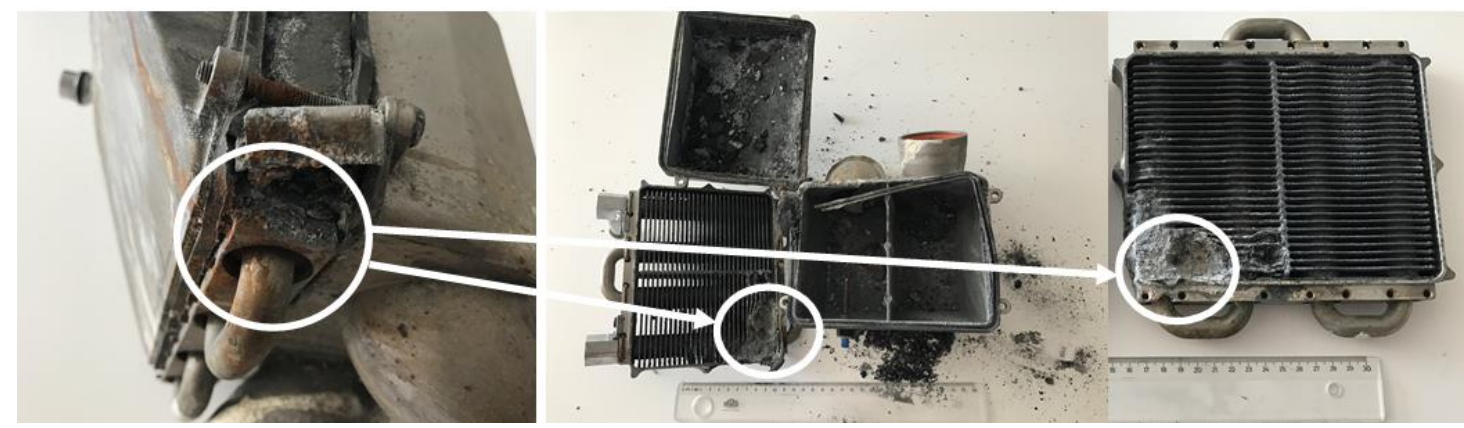

Şekil 5. Korozyona maruz kalan reküperatör sisteminde bakır boru ve alüminyum 1sı değiștiricinin temasta olduğu bölge. 


\begin{tabular}{|c|c|c|}
\hline & $\begin{array}{l}\text { BŞEÜ Fen Bilimleri Dergisi } \\
6(2), 327-335,2019\end{array}$ & $\begin{array}{r}\text { BSEU Journal of Science } \\
\text { DOI: } 10.35193 / \text { bseufbd.569182 }\end{array}$ \\
\hline $\begin{array}{l}\text { BiLECCKSEYH EDEBALI } \\
\text { UNIVERSITES }\end{array}$ & & e-ISSN: 2458-7575 (http://dergipark.gov.tr/bseufbd) \\
\hline
\end{tabular}

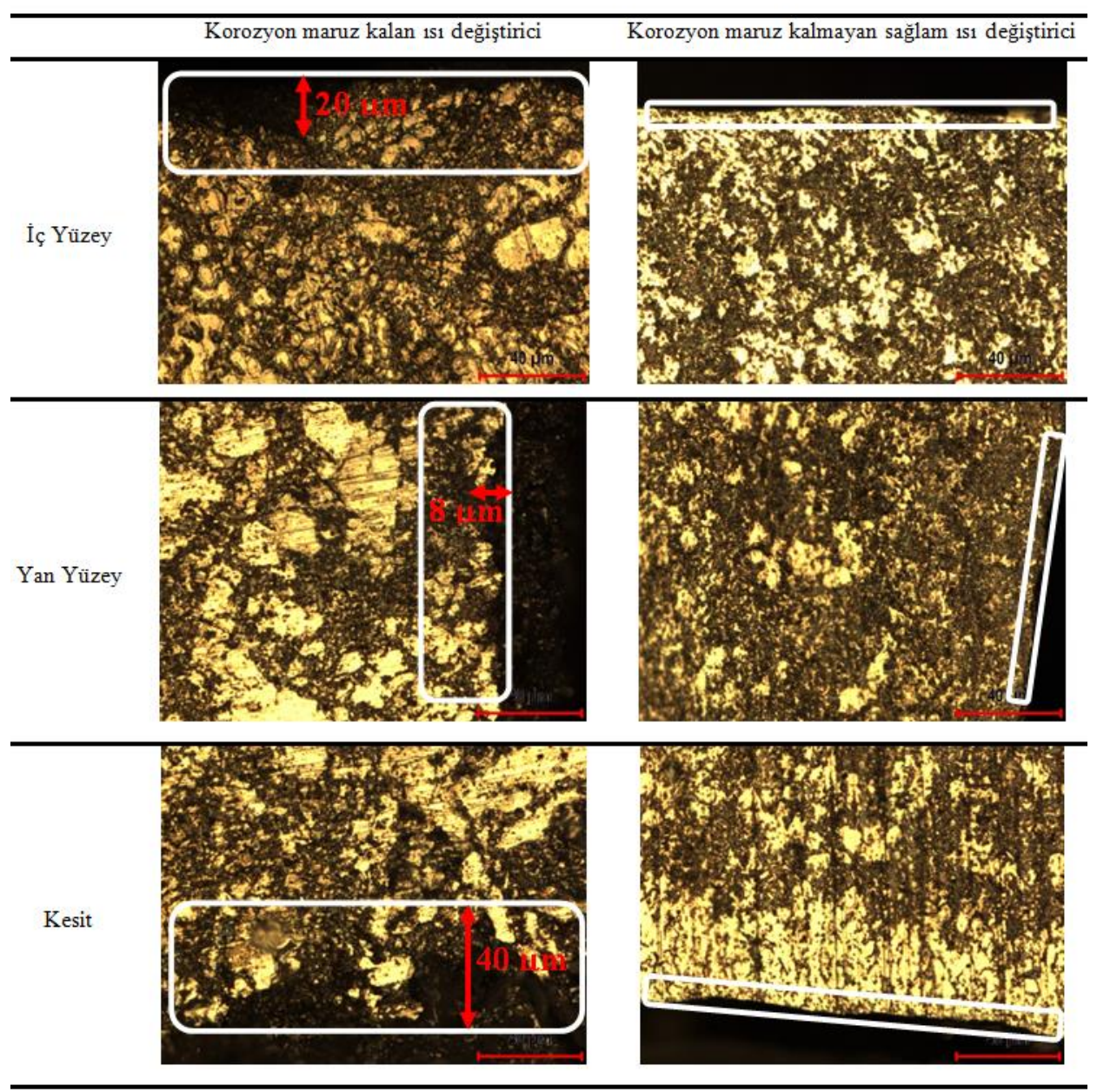

Şekil 6. Korozyona maruz kalan 1sı değiştirici ve korozyona maruz kalmayan sağlam ısı değiştiricinin iç yüzey, yan yüzey ve kesitlerine ait OM görünümleri (X500).

Korozyona maruz kalmayan sağlam 1sı değiştiricisinin iç yüzey ve kesitinden alınan alüminyum alaşımının \% 3,5 NaCl çözeltisi içerisindeki zamana bağlı olarak azalan eğilimde açık devre potansiyelindeki dalgalanmalar (Şekil 7 a) korozyonun oyuklanma şeklinde geliştiğini gösteren korozyon çukurları Şekil 8'de görülmektedir. Benzer davranış, Sakairi ve arkadaşları tarafından rapor edilmiştir [5]. Polarizasyon eğrileri (Şekil 7 b) ve yüzey görüntüleri (Şekil 8) beraber değerlendirildiğinde, iç yüzey ve kesitin benzer korozyon davranışı sergilediği ve korozyonun oyuklanma (daire içinde) şeklinde geliştiğini göstermektedir. 


\begin{tabular}{|c|c|c|}
\hline & $\begin{array}{l}\text { BŞEÜ Fen Bilimleri Dergisi } \\
6(2), 327-335,2019\end{array}$ & $\begin{array}{r}\text { BSEU Journal of Science } \\
\text { DOI: } 10.35193 / \text { bseufbd.569182 }\end{array}$ \\
\hline $\begin{array}{l}\text { BilLeCIKSEYHEDEBALL } \\
\text { UNIVERSITESI }\end{array}$ & & e-ISSN: $2458-7575$ (http://dergipark.gov.tr/bseufbd) \\
\hline
\end{tabular}

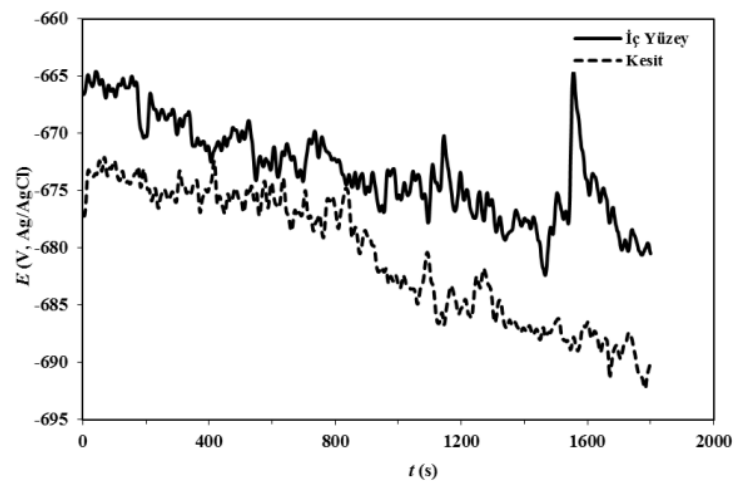

(a)

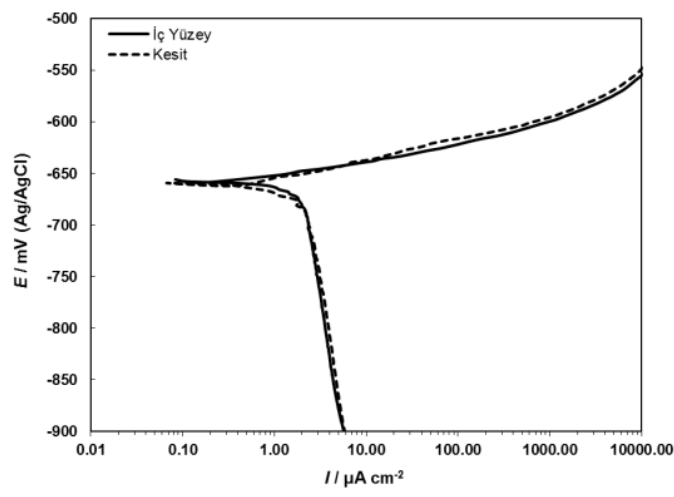

(b)

Şekil 7. Korozyona maruz kalmayan sağlam 1sı değiştiricisinin iç yüzey ve kesitine ait alüminyum alaşımının \% $3,5 \mathrm{NaCl}$ çözeltisi içerisindeki (a) açık devre potansiyeli ve (b) polarizasyon eğrileri.

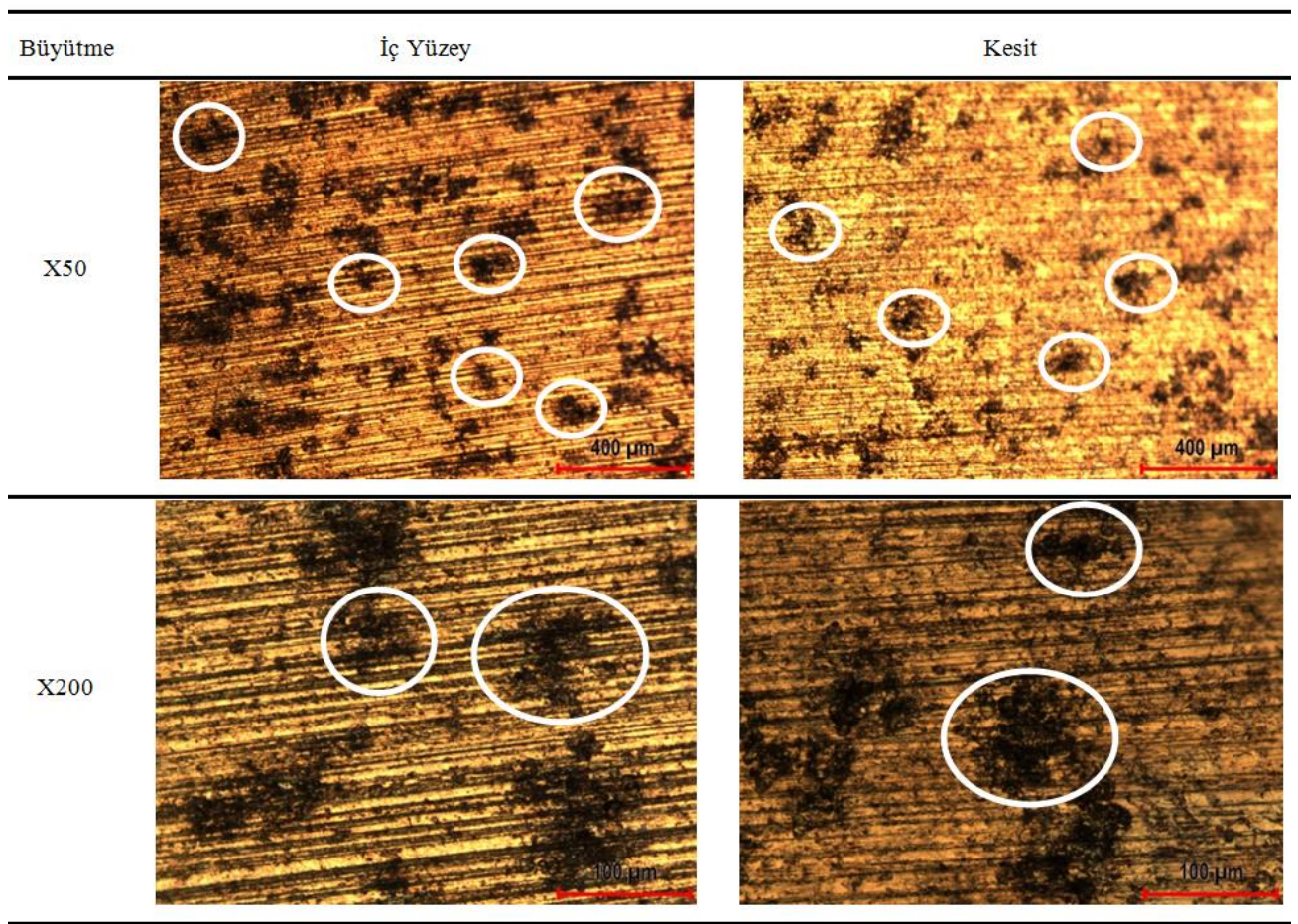

Şekil 8. Potansiyostatik polarizasyon yöntemine göre korozyon deneyleri yapılan alüminyum alaşımının iç yüzey ve kesitin OM yüzey görüntüleri (daire içinde oyuklar gösterilmiştir).

\section{SONUÇLAR}

Tedarikçi firmadan, korozyona uğrayan ve korozyona maruz kalmayan kanat yüzeyli borulu 1S1 değiştirici numunelerin yüzeyleri ve enine kesitleri karşılaştırılarak elde edilen sonuçlar sıralanmıştır;

Korozyona uğrayan reküperatör sistemi incelendiğinde korozyonun nedeni alüminyum 1sı değiştirici ile bakır borunun birbirleri ile temas halinde bulunmasından ve aralarından akım geçişine müsait bir ortamda bulunmalarından dolayı oluşan galvanik korozyondur. Bu tür galvanik eşlemeler çoğunlukla bir tasarım veya imalat gereksinimi olarak karşımıza çıkmaktadır. Bu nedenle, galvanik eşlemenin zorunlu olduğu hallerde 
galvanik dizide birbirlerine yakın metal ve alaşımların seçilmesi önem taşımaktadır. Bu tür eşlemeler kaçınılmaz bir zorunluluk olarak ortaya çıkması durumunda iki metal arasındaki bağlantılar yalıtkan conta, ara parça veya kaplama ile izole edilmelidir.

Korozyona uğrayan alüminyum 1sı değiştiricinin iç yüzey, yan yüzey ve kesitleri incelendiğinde iç ve yan yüzeylere nazaran yer çekim kuvveti etkisi ile akışkanın daha çok temasta olduğu kesitte korozyonun daha şiddetli oluştuğu gözlenmiş̧tir.

Korozyona maruz kalmayan sağlam 1sı değiştiricinin yüzey ve kesitinden alınan alüminyum alaşımının \% 3,5 NaCl çözeltisi içerisindeki potansiyodinamik polarizasyon eğrileri ve korozyon yüzeyleri incelendiğinde korozyonun oyuklanma şeklinde geliştiği ve benzer korozyon davranışı sergilediği tespit edilmiştir.

\section{REFERANSLAR}

[1] Danışman, C. (2010). Plakalı eşanjör etkinlik parametrelerinin deneysel analizi, Yüksek Lisans Tezi, Osmangazi Üniversitesi Fen Bilimleri Enstitüsü, Eskişehir.

[2] Kılıç, B. (2008). Plakalı 1sı eşanjörlerinin ısıtma ve soğutma uygulamaları için optimum çalışma şartlarının araştırılması, Yüksek Lisans Tezi, Süleyman Demirel Üniversitesi Fen Bilimleri Enstitüsü, Isparta.

[3] Davis, J.R., Ed. (1999). ASM Handbook, Corrosion of Aluminum and Aluminum Alloys. ASM International, USA.

[4] Saglam, U., Baydogan, M., Mindivan, H., Kayalı, E.S., Cimenoglu, H. (2004). Influence of retrogression and reageing on mechanical and corrosion properties of 7039 aluminium alloy. Zeitschrift für Metallkunde, 95, 14-17.

[5] Sakairi, M., Sasaki, R., Kaneko, A., Seki, Y., Nagasaw, D. (2014). Evaluation of metal cation effects on galvanic corrosion behavior of the A5052 aluminum alloy in low chloride ion containing solutions by electrochemical noise impedance. Electrochimica Acta, 131, 123-129. 